\section{EVALUATION ON THE EGFET PH SENSING PERFORMANCE OF SOL-GEL SPIN COATED TITANIUM DIOXIDE THIN FILM}

Muhammad AlHadi Zulkeflea,b, Sukreen Hana Hermana*, Rohanieza Abdul Rahman ${ }^{a, b}$, Khairul Aimi Yusofa,b, Aimi Bazilah Roslia,b, Wan Fazlida Hanim Abdullaha, Zurita Zulkiflib

Integrated Sensors Research Group, Faculty of Electrical Engineering, University Teknologi MARA, 40450 Shah Alam, Selangor, Malaysia

bNANO-ElecTronic Centre, Faculty of Electrical Engineering, University Teknologi MARA, 40450 Shah Alam, Selangor, Malaysia
Article history

Received

17 November 2020

Received in revised form

7 April 2021

Accepted

19 May 2021

Published online

20 June 2021

*Corresponding author hana1617@uitm.edu.my

\section{Graphical abstract}

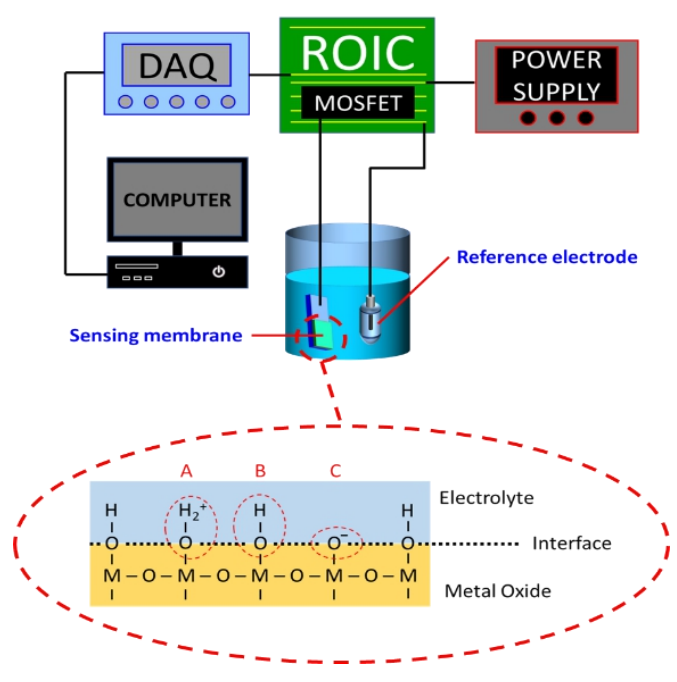

\begin{abstract}
For this study, $\mathrm{TiO}_{2}$ thin film was fabricated using sol-gel spin coating method. The fabricated film was then applied as sensing membrane in an extended gate field effect transistor (EGFET) $\mathrm{pH}$ sensor system. The $\mathrm{pH}$ sensing performance of the sol-gel spin coated $\mathrm{TiO}_{2}$ were evaluated in terms of sensitivity, linearity and hysteresis where the value obtained was 58.70 $\mathrm{mV} / \mathrm{pH}, 0.9922$ and $86.17 \mathrm{mV}$ respectively. The drift rate of the sample when being measured for 12 consecutive hours was also determined where measurement in $\mathrm{pH} 4, \mathrm{pH} 7$ and $\mathrm{pH} 10$ yield drift rate of $1.72 \mathrm{mV} / \mathrm{h}, 4.14 \mathrm{mV} / \mathrm{h}$ and $6.05 \mathrm{mV} / \mathrm{h}$ respectively. Besides that, the $\mathrm{TiO}_{2}$ was characterized for its thickness $(24.32 \mathrm{~nm})$ and surface roughness $(5.129 \mathrm{~nm})$. From the results obtained, it was found that sol-gel spin coated $\mathrm{TiO}_{2}$ thin film with thickness between 20 - $29 \mathrm{~nm}$ will have high $\mathrm{pH}$ sensitivity (more than $50 \mathrm{mV} / \mathrm{pH}$ ).
\end{abstract}

Keywords: EGFET, pH sensors, sol-gel spin coating, thickness, thin films, titanium dioxide

\begin{abstract}
Abstrak
Untuk kajian ini, filem nipis $\mathrm{TiO}_{2}$ telah difabrikasi menggunakan kaedah salutan putaran sol-gel. Filem yang telah difabrikasi kemudian digunakan sebagai membran pengesan di dalam sistem sensor $\mathrm{pH}$ 'extended gate field effect transistor'. Prestasi pengesanan $\mathrm{pH}$ oleh $\mathrm{TiO}_{2}$ salutan putaran sol-gel telah dinilai dari segi kepekaan, linearity dan hysteresis di mana nilai yang diperoleh masing-masing adalah $58.70 \mathrm{mV} / \mathrm{pH}, 0.9922$ dan $86.17 \mathrm{mV}$. Kadar drift sampel ketika diukur selama 12 jam berturut-turut juga telah ditentukan di mana pengukuran dalam $\mathrm{pH} 4, \mathrm{pH} 7$ dan $\mathrm{pH} 10$ menghasilkan kadar drift masing-masing adalah $1.72 \mathrm{mV} / \mathrm{h}, 4.14 \mathrm{mV} / \mathrm{h}$ dan $6.05 \mathrm{mV} / \mathrm{h}$. Selain itu, $\mathrm{TiO}_{2}$ juga dicirikan untuk ketebalannya $(24.32 \mathrm{~nm})$ dan kekasaran permukaan (5.129 nm). Dari keputusan yang diperoleh, telah didapati bahawa filem nipis $\mathrm{TiO}_{2}$ salutan putaran sol-gel dengan ketebalan antara $20-29 \mathrm{~nm}$ akan mempunyai kepekaan $\mathrm{pH}$ yang tinggi (lebih dari $50 \mathrm{mV} / \mathrm{pH}$ ).
\end{abstract}

Kata kunci: EGFET, sensor pH, salutan putaran sol-gel, ketebalan, filem nipis, titanium dioxide 


\subsection{INTRODUCTION}

$\mathrm{pH}$ measurement is vital for various purposes. Agriculture area [1], construction sector, medical field [2-3] and food processing [4] all are $\mathrm{pH}$ dependent. Cheap litmus paper is extremely good for acid, neutral and basic solution differentiation but unsuitable when precise measurement is needed. Glass pH electrode is popular since it gives accurate $\mathrm{pH}$ measurement but suffers drawbacks of mechanical fragility making it unfit to be used in some applications especially in in-vivo measurement [5]. To solve this, Bergveld [6] introduced an alternative $\mathrm{pH}$ sensing structure known as ion sensitive field effect transistor (ISFET). Based on MOSFET operating principle, ISFET showed promising performance with $\mathrm{pH}$ sensitivity more than $50 \mathrm{mV} / \mathrm{pH}$.

The only problem arose was that the MOSFET used was being immersed along with $\mathrm{pH}$ sensitive part during the measurement process. This makes ISFET somewhat unreliable when dealing with temperature and light as well as having issues of ionic penetration. A simple yet effective solution was proposed by Spiegel et. al [7] to eliminate the problem faced by ISFET. By extending the gate from the MOSFET, the sensing membrane now no longer needed to be fabricated directly on MOSFET. Thus the MOSFET does not need to be immersed in solutions being measured. This extended structure is considered as successor to ISFET and known as extended gate field effect transistor (EGFET). EGFET $\mathrm{pH}$ sensing structure offers significant advantages such as light and thermal stability, simpler packaging and dimensional flexibility of the sensing membrane [8].

Common method of measuring $\mathrm{pH}$ is by using glass electrode because of its sensitivity. However, since it is glass-built nature, the glass electrode is large in size, difficult to be miniaturized and mechanically fragile [9]. Besides that, glass electrode used for $\mathrm{pH}$ measurement needs internal solution, complicating its fabrication process. It also requires high maintenance since need to be immersed in a specialized solution when not being in used and periodically calibrated [10]. All solid-state sensing membrane is therefore more favored compared to glass $\mathrm{pH}$ electrode. Some of sensing membrane type popularly used is metal nitride based and metal oxide based. These groups of material have special properties on its surface, enabling it to interact with hydrogen ions in liquid solutions.

In case of metal oxide, it has surface hydroxyl groups which can protonate and deprotonate at moment of contact with hydrogen ions in solutions, producing surface potential [11]. When being used as sensing membrane for EGFET $\mathrm{pH}$ sensor, the surface potential at metal oxide-electrolyte interface would change the amount of current that can flow between source and drain in the MOSFET used. The amount of current is dependent on amount of hydrogen ions available in measured solution and these would affect the output voltage, $V_{\text {out }}$ reading of EGFET $\mathrm{pH}$ sensor. Based on output voltage obtained, the $\mathrm{pH}$ values of solutions can be determined, and vice versa.

The performance of metal oxide as $\mathrm{pH}$ sensing membrane however is highly associated with its fabrication process. Metal oxide such as titanium dioxide can be produced through many deposition methods such as chemical vapor deposition, sputtering, dip coating, spin coating, spray pyrolysis and pulsed laser deposition [12]. Comparing all of the techniques, sol-gel spin coating is considered the most compelling film forming method because of its simplicity, low cost, low temperature deposition and final product properties [13].

There are several characterizations that can be done to study the sensing performance of a thin film when measuring $\mathrm{pH}$. In this work, the $\mathrm{pH}$ sensitivity, linearity, hysteresis and drift characteristics of the fabricated $\mathrm{TiO}_{2}$ thin film was measured and determined. Besides that, a range of ideal thickness for a sol-gel spin coated based $\mathrm{TiO}_{2} \mathrm{pH}$ sensing membrane was proposed in this work.

\subsection{METHODOLOGY}

Ultrasonic cleaning of electrically conductive indium tin oxide (ITO) substrate was performed using Hwashin Technology Powersonic 405 ultrasonic cleaner. The cleaning solution used was methanol and deionized water. Inert argon gas was then used to blow-dry the cleaned substrate.

The sol-gel used was $0.1 \mathrm{M} \mathrm{TiO}_{2}$ solution. The solgel was obtained by mixing titanium (IV) isopropoxide (Sigma-Aldrich, 97\%) precursor with deionized water (Milli-Q Advantage A10) for it to undergo hydrolysis process. The solvent, stabilizer and surfactant used was absolute ethanol (SYSTERM, 99.8\%), glacial acetic acid (Friendemann Schmidt, 99.8\%) and Triton X-100 (R\&M Chemicals, 98\%) respectively. The mixture was stirred for 2 hours using Stuart Digital Hotplate Stirrer CD162 to obtain homogenous and clear solution.

To deposit $\mathrm{TiO}_{2}$ in form of thin film, spin coater (Laurell Model WS-650MZ-8NPP/LITE) was used. The process was started by positioning cleaned ITO substrate on top of the spin coater's chuck. Then, 10 drops of prepared $\mathrm{TiO}_{2}$ sol-gel was dropped on top of the substrate. The speed of the substrate being rotated during the sol-gel deposition was $500 \mathrm{rpm}$. After the deposition was done, the rotational speed of the substrate was increased to $3000 \mathrm{rpm}$ for 1 minutes. During this high-speed spinning, the deposited solution would be uniformly distributed across substrate surface by the action of centrifugal force.

After spinning process had finished, the substrate was removed from the spin coater's chuck. To remove the excess solvent from the film, drying process was conducted at temperature of $100^{\circ} \mathrm{C}$ for 10 minutes and the film was then subsequently annealed for 15 minutes at $400{ }^{\circ} \mathrm{C}$ to remove any 
organic residues. All the heat treatment was performed using Protherm Furnace PLF 160/5.

The dried and annealed $\mathrm{TiO}_{2}$ thin film was used as sensing membrane for EGFET $\mathrm{pH}$ sensor. This was done by connecting it to the gate of a commercialized MOSFET using copper wire, forming the EGFET configuration. The MOSFET was attached to a constant voltage constant current (CVCC) readout interface circuit (ROIC) [14]. The output voltage, $V_{\text {out }}$ from the ROIC was recorded by Keysight U2356A 64CH Multifunction data acquisition (DAQ). The setup used was shown in Figure 1.

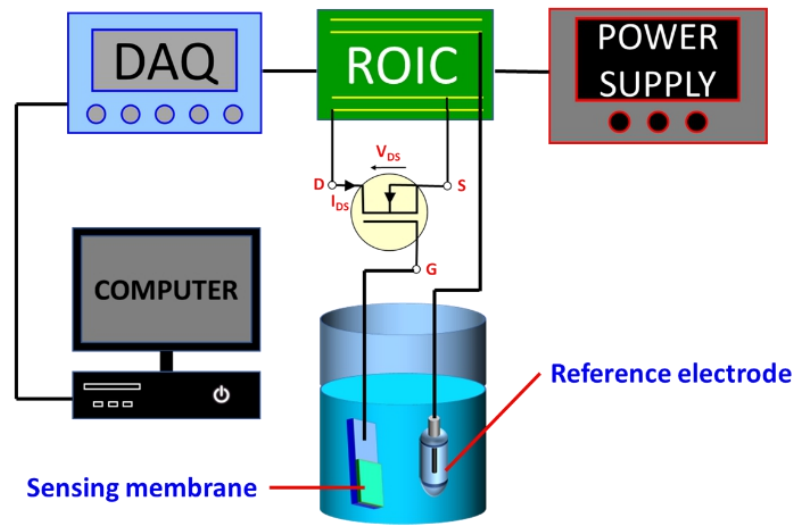

Figure 1 EGFET pH measurement setup

\subsection{RESULTS AND DISCUSSION}

Using surface profilometer, thickness of the $\mathrm{TiO}_{2}$ thin film was measured and was found to be at $24.32 \mathrm{~nm}$. The surface of the sample was scanned using atomic force microscope (AFM) and the resulting image was shown in Figure 2. The average roughness, $R_{a}$ of the surface of the sample was $5.129 \mathrm{~nm}$. Besides that, EDX characterization was performed. The peaks representing elements present on the sample was shown in Figure 3 with $\mathrm{Ti}$ and $\mathrm{O}$ confirmed to be existed. Besides that, peak of elements from the substrate namely Si, In and Sn was also observed.

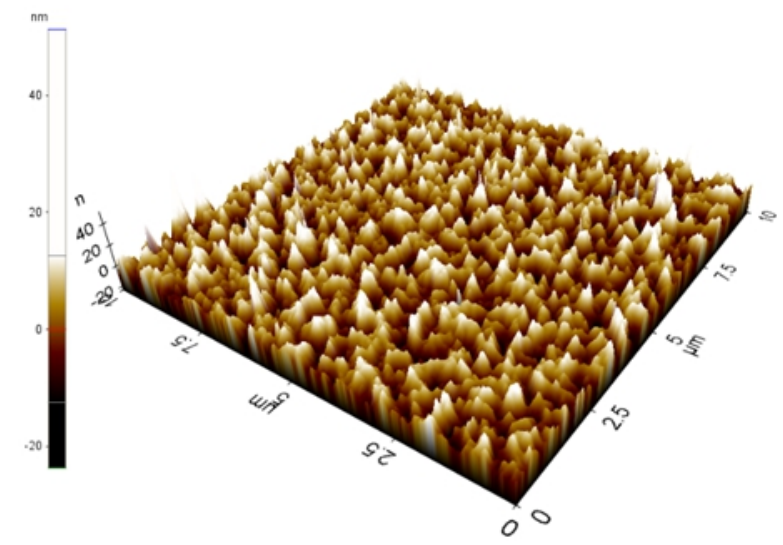

Figure 2 AFM 3D image showing surface morphology of the spin coated $\mathrm{TiO}_{2}$ thin film

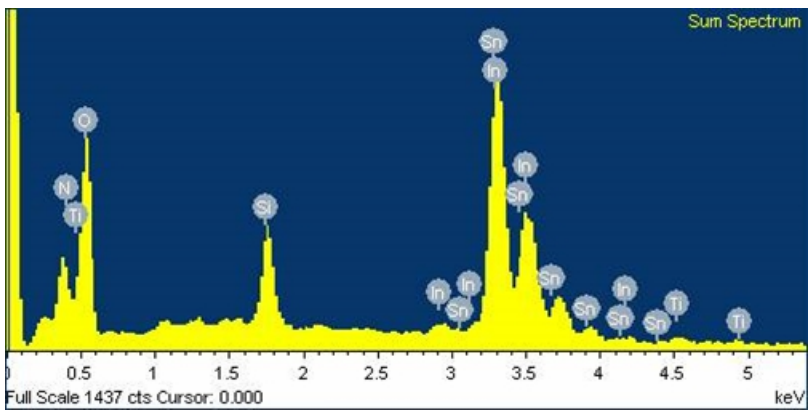

Figure $3 \mathrm{EDX}$ spectra of the $\mathrm{TiO}_{2}$ thin film

For $\mathrm{pH}$ sensor, the most important characteristic is that it must possessed good sensitivity. Sensitivity is a measurement in which the sensitive layer, here the $\mathrm{TiO}_{2}$ thin film, was evaluated for its ability to interact with hydrogen ions in the solution. Higher sensitivity value means better sensing performance and ideal sensitivity was derived from Nernst equation, shown in Equation 1 [15].

$$
E=E^{\circ}-\frac{0.0592 V}{n} \log Q
$$

in which $E, E^{\circ}, n$ and $Q$ are cell potential, standard cell potential, number of electrons and reaction quotient respectively. From the equation, the ideal sensitivity that was desired is $0.0592 \mathrm{~V}$ or 59.2 $\mathrm{mV}$. In $\mathrm{pH}$ sensor term, this value means that for every change of $1 \mathrm{pH}$ value of solution, the voltage produced has $59.2 \mathrm{mV}$ differences. In an EGFET sensor system, since the sensitivity was directly extracted from the slope of the graph of output voltage versus $\mathrm{pH}$ value, the output voltage is considered an important aspect of the measurement. To understand how output voltage was obtained using EGFET system, $\mathrm{pH}$ sensing mechanism and MOSFET working principle must be understood. $\mathrm{TiO}_{2}$ was chosen as the sensing membrane since as a metal oxide, its surface has hydroxyl groups [16-17]. These hydroxyl groups were capable of interacting with $\mathrm{pH}$ potential determining ions (PDI) that is hydrogen ions and hydroxide ions.

When a PDI comes into contact with the hydroxyl group, the hydroxyl group will either protonate (donate electron) or deprotonate (accept electron) [18], shown in the Figure 4. Thus depending on the type of PDI that is dominant in the solution (hydrogen ions in acidic solution while hydroxide ions in basic solution), the surface of the sensing membrane will be either be more positively or more negatively charged. This is measured in term of surface potential following the Equation 2 below: 


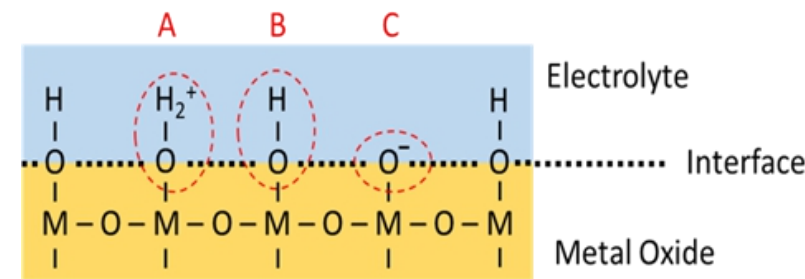

Figure 4 Basic reaction on metal oxide surface producing surface potential (a) protonation (b) neutral condition (c) deprotonation

$$
2.303\left(p H_{p z c}-p H\right)=\frac{q \Psi_{0}}{k T}+\sinh ^{-1}\left(\frac{q \Psi_{0}}{k T} \cdot \frac{1}{\beta}\right)
$$

where $\mathrm{pH}_{\mathrm{pzc}}$ is $\mathrm{pH}$ value at point of zero charge, $\mathrm{q}$ is electron charge, $\psi_{0}$ is the surface potential, $\mathrm{k}$ is Boltzmann's constant, $T$ is absolute temperature and $\beta$ is the sensitivity parameter. The surface potential would determine the amount of current that may flow between the source and drain (lDS) in the MOSFET. The IDS would then influence the resultant output voltage and hence the sensitivity value of the sample. In short, the output voltage is dependent on the amount or concentration of PDI available in the solution.

Graph correlating output voltage and $\mathrm{pH}$ value was plotted as in Figure 5. The sensitivity and linearity value of the sample was extracted from the slope and regression value of the graph respectively. As a result, the $\mathrm{pH}$ sensitivity of the sample was found to be at $58.70 \mathrm{mV} / \mathrm{pH}$ while its linearity was 0.9922 . This value is considered high and also obey the Nernstian theoretical response of $59 \mathrm{mV} / \mathrm{pH}$ [19].

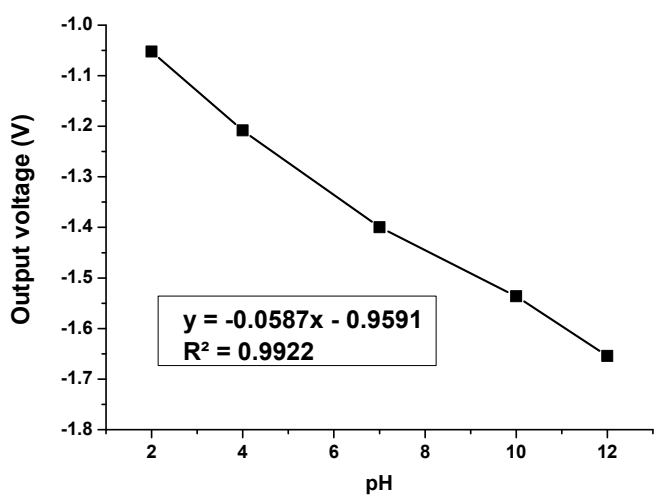

Figure 5 Output voltage vs $\mathrm{pH}$ value

In a metal oxide-based $\mathrm{pH}$ sensing membrane, another sensing performance evaluation that was usually studied is the hysteresis measurement. Hysteresis effects refers to the changes in reading after the sample being measured in $\mathrm{pH}$ buffer solutions of different value. It involves measuring the output voltage of sample when being immersed in a loop of $\mathrm{pH}$ buffer in a given time. There are generally two kind of hysteresis measurement can be done; acid-site or basic-site. For example, in an acid-site measurement, the $\mathrm{pH}$ loop is 7-4-7-10-7 while for basic-site, the $\mathrm{pH}$ loop is 7-10-7-4-7.

It basically means either the measurement starts (after being immersed in $\mathrm{pH}$ 7) with measurement in acidic media or basic media. In this particular study, acid-site hysteresis measurement was performed. The $\mathrm{pH}$ loop is 7-4-7-10-7 in a period of 600 seconds. The graph of the result from the hysteresis measurement is shown in Figure 6 below. The hysteresis of the sample was determined by measuring the difference of output voltage between initial and final reading $\left(\Delta \mathrm{V}_{\text {out }}\right)$ during the hysteresis measurement.

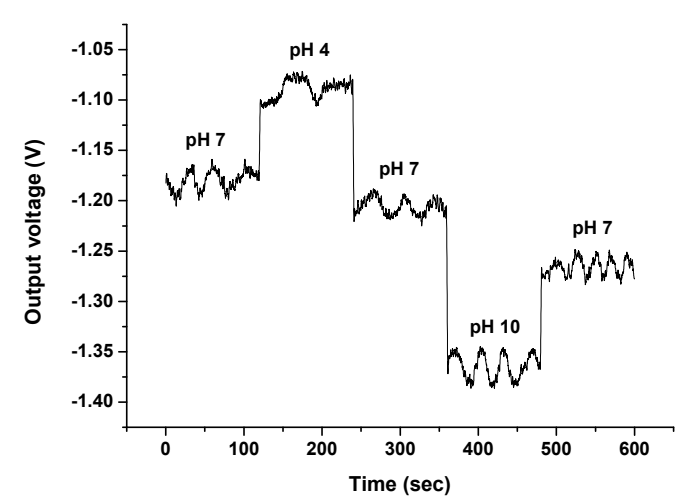

Figure 6 Hysteresis characteristics of spin coated $\mathrm{TiO}_{2}$ EGFET $\mathrm{pH}$ sensor

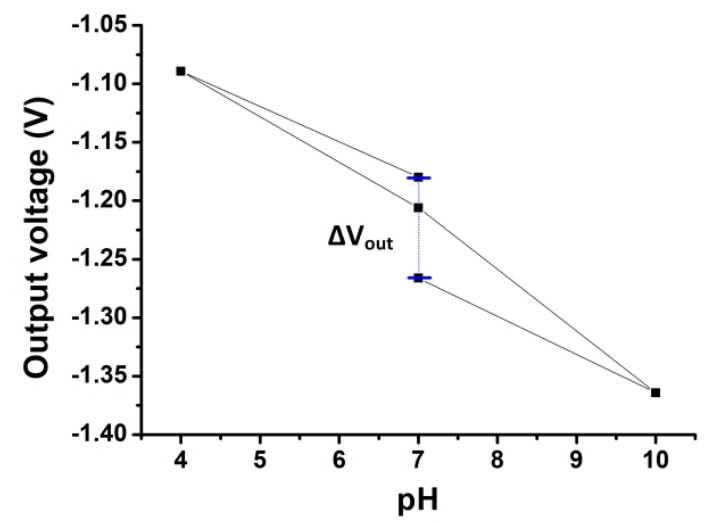

Figure 7 Hysteresis width of the spin coated $\mathrm{TiO}_{2}$ EGFET pH sensor

The $\Delta \mathrm{V}_{\text {out }}$ can also be called hysteresis width, $\mathrm{H}_{\mathrm{w}}$ and in this work, the $\mathrm{H}_{\mathrm{w}}$ for the $\mathrm{TiO}_{2}$ thin film is 86.17 $\mathrm{mV}$ (shown in Figure 7). Hysteresis is also known as memory effect where this abnormality is caused by presence of buried $\mathrm{OH}$ site beneath the surface of inorganic $\mathrm{pH}$ sensitive membrane [20]. Number of buried sites is expected to be lower than available on surface, but $\mathrm{H}^{+}$and $\mathrm{OH}^{-}$ions can diffuse slowly into the surface [21]. This very slow response resulted in apparent delay or hysteresis effects experienced by the sensing membrane [22].

The reliability of the sensing membrane is further investigated in which the sensing performance of the $\mathrm{TiO}_{2}$ film is studied for an extended period of time. This was done to study the drift characteristic of the 
fabricated sample. Drift is a phenomenon [23] in which the value of reading changes over time when being measured in a fixed value of $\mathrm{pH}$ buffer solution. In this work, the $\mathrm{TiO}_{2}$ sensing membrane was immersed in the same $\mathrm{pH}$ buffer solution $\mathrm{pH} \mathrm{4,7}$ and 10) for 12 consecutive hours. The $V_{\text {out }}$ produced were recorded by the DAQ and was plotted in the graph in Figure 8.

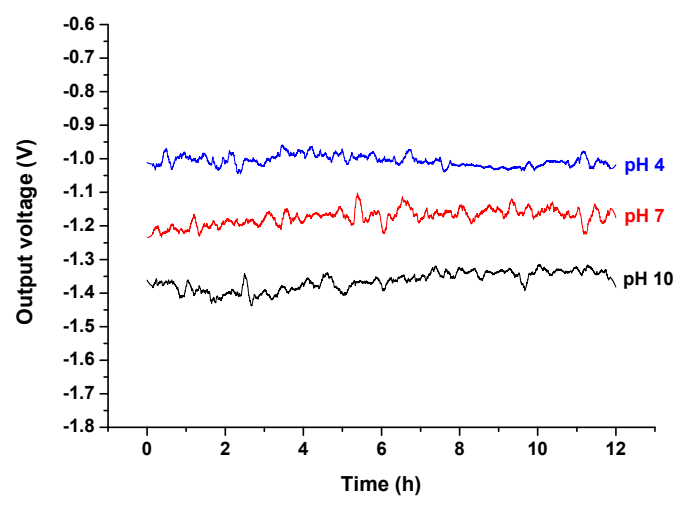

Figure 8 Drift characteristics of the spin coated $\mathrm{TiO}_{2}$ thin film $\mathrm{pH}$ sensor measured for 12 consecutive hours

The drift of the sensing membrane when being measured in $\mathrm{pH} 4$ buffer solution is quite small with drift rate of only 1.72 millivolt per hour $(\mathrm{mV} / \mathrm{h})$. When solution with $\mathrm{pH}$ value of 7 was used, the drift rate increases to $4.14 \mathrm{mV} / \mathrm{h}$. Highest drift rate of $6.05 \mathrm{mV} / \mathrm{h}$ was observed when the measurement was done in buffer solution of $\mathrm{pH} 10$.

From the result, it was noticed that drift values become larger as solution's $\mathrm{pH}$ value increases. The dependent of drift on $\mathrm{pH}$ value could be related to the amount of potential determining ions, $\mathrm{H}^{+}$and $\mathrm{OH}^{-}$ present. Higher $\mathrm{pH}$ means higher numbers of $\mathrm{OH}^{-}$. This means that the increase in drift was influenced by higher amount of $\mathrm{OH}^{-}$in the solutions [24]. This phenomenon on drift-pH increment is also observed in other type of $\mathrm{pH}$ sensitive materials [25-26].

Deviation of output voltage as a result of prolong measurement is an issue commonly occurred in metal oxide based ISFET pH sensor. EGFET, a successor to ISFET sensor structure also possessed this long-term drift effects, as shown in this study. It is suggested that drift may be caused by several possibilities; variation of the surface state density, slow surface effects, drift of sodium ions or by injection of electrons from the electrolyte [20].

Sol-gel spin coating process was also used to fabricate $\mathrm{TiO}_{2}$ thin films while varying other parameters, resulting in films with different thickness. The film's thickness seems to affect the $\mathrm{pH}$ sensitivity of the samples when being used as sensing membrane for EGFET pH sensor structure, as shown in Figure 9.

From Figure 9, the increase in film thickness seems to improve the $\mathrm{pH}$ sensitivity of $\mathrm{TiO}_{2}$. Increase in film thickness in the same fixed area, can be related to the increase of $\mathrm{TiO}_{2}$ particles in the volume element of the thin films as it becomes thicker. We take into account the region that involves in the $\mathrm{pH}$ sensing mechanism which is the surface and the region below the surface, more $\mathrm{TiO}_{2}$ particles in the region means more oxygen atoms concentration per unit area. The thickness of this region and the concentration of the oxygen atoms were reported to be among the determining factor of the surface hydroxyl groups concentration [27]. With the increase of $\mathrm{TiO}_{2}$ particles concentrations, more hydroxyl groups become available on the surface of the film to enhance more interaction with PDIs and thus improve the sensitivity. However, based on [27], the determining factors are based on the region below the surface area and not the bulk of the thin film. Hence further increasing the film thickness will not improve the sensor sensitivity. Thicker films were also reported to be less sensitive than thinner films due to the formation of internal potential difference between the thin film surface and the substrate [28]. This affects the flow of current to the MOSFET and thus may lowered the sensitivity of the sensor.

It was also noticed in Figure 9 that in order for a $\mathrm{TiO}_{2}$ thin film to possessed great $\mathrm{pH}$ sensitivity above $50 \mathrm{mV} / \mathrm{pH}$ (data in circle), the film thickness must be between $20 \mathrm{~nm}-29 \mathrm{~nm}$ range. Most of the sample that has thickness lower and higher that this range would most probably has sensitivity lower than 50 $\mathrm{mV} / \mathrm{pH}$. Although sensitivity above $40 \mathrm{mV} / \mathrm{pH}$ is still consider good, for usage in important applications that require high precision $\mathrm{pH}$ measurement, a high sensitivity sensing membrane near Nernstian value (59 $\mathrm{mV} / \mathrm{pH})$ is needed. But it is noteworthy to note that this range of thickness was obtained using $\mathrm{TiO}_{2}$ sample with sol-gel concentration of $0.1 \mathrm{M}$ and might differs if different concentration is used.

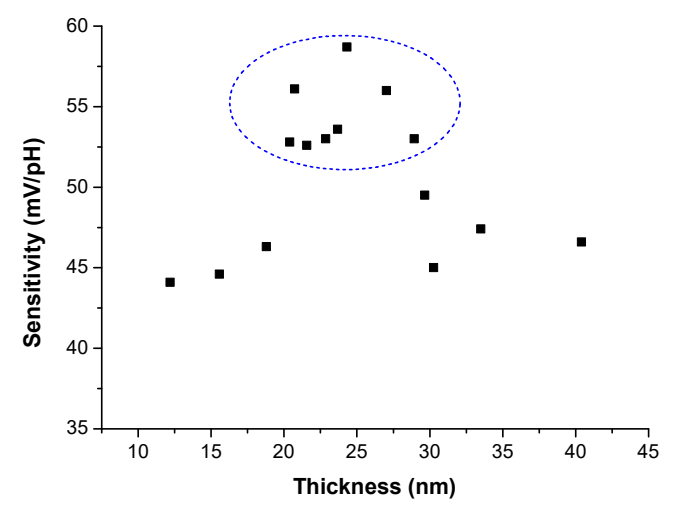

Figure $9 \mathrm{pH}$ sensitivity dependency on thickness of sol-gel spin coated $\mathrm{TiO}_{2}$ thin films

\subsection{CONCLUSION}

Sol-gel spin coating method was used to fabricate $\mathrm{pH}$ sensitive $\mathrm{TiO}_{2}$ thin film. The thickness of the produced film was found to be at $24.32 \mathrm{~nm}$ while the surface roughness is $5.129 \mathrm{~nm}$. Using EGFET sensor 
measurement setup, the film $\mathrm{pH}$ sensing characteristics were determined through measurement of sensitivity $(58.70 \mathrm{mV} / \mathrm{pH})$, linearity (0.9922), hysteresis $(86.17 \mathrm{mV})$ and drift $(4.14 \mathrm{mV} / \mathrm{h}$ at $\mathrm{pH} 7)$. A range of sol-gel spin coated $\mathrm{TiO}_{2}$ film thickness that can result in highly $\mathrm{pH}$ sensitive film (more than $50 \mathrm{mV} / \mathrm{pH}$ ) was also successfully determined in this work. The thickness range was found to be at $20 \mathrm{~nm}$ to $29 \mathrm{~nm}$.

\section{Acknowledgement}

This study was partially supported by MOSTI Malaysia under the International Collaboration Fund (ICF) (Grant number: IF1019/1136). Authors acknowledge the technical support from NANO-SciTech Centre (NST), UiTM.

\section{References}

[1] Neina, D. 2019. The Role of Soil pH in Plant Nutrition and Soil Remediation. Applied and Environmental Soil Science. 2019: 5794869.

DOI: https://doi.org/10.1155/2019/5794869.

[2] Kuo, S., Shen, C. and Shen, C. 2020. Role of pH Value in Clinically Relevant Diagnosis. Diagnostics. 10(2): 107. DOI: https://doi:10.3390/diagnostics 10020107.

[3] Aoi, W. and Marunaka, Y. 2014. Importance of pH Homeostasis in Metabolic Health and Diseases: Crucial Role of Membrane Proton Transport. BioMed Research International. 2014: 598986.

DOI: http://dx.doi.org/10.1155/2014/598986.

[4] Andres-Bello, A., Barreto-Palacios, V., Garcia-Segovia, P. Mir-Bel, J. and Martinez-Monzo, J. 2013. Effect of pH on Color and Texture of Food Products. Food Engineering Reviews. 5: 158-170.

DOI: https://doi:10.1007/s12393-013-9067-2

[5] Ghoneim, M. T., Nguyen, A., Dereje, N., Huang, J., Moore, G. C., Murzynowski, P. J. and Dagdevien, C. 2019. Recent Progress in Electrochemical pH-Sensing Materials and Configurations for Biomedical Applications. Chemical Reviews. 119: 5248-5297. DOI: https://doi.org/10.1021/acs.chemrev.8b00655

[6] Bergveld, P. 1972. Development, Operation, and Application of the Tool for Electrophysiology. IEEE Transactions on Biomedical Engineering. 342-351. DOI: https://doi:10.1 109/TBME.1972.324137.

[7] Van der spiegel, J., Lauks, I., Chan, P. and Babic, D. 1983. The Extended Gate Chemically Sensitive Field Effect Transistor as Multi-species Microprobe. Sensors and Actuators. 4: 291-298.

DOI: https://doi.org/10.1016/0250-6874(83)85035-5.

[8] Yang, C.-C., Chen, K.-Y. and Su, Y.-K. 2019. $\mathrm{TiO}_{2} \mathrm{Nano}$ Flowers Based EGFET Sensor for pH Sensing. Coatings. 9(4): 251. DOI: https:// doi:10.3390/coatings9040251.

[9] Xu, K., Kitazumi, Y., Kano, K. and Shirai, O. 2019. Electrochemistry Communications Electrochemical pH Sensor Based on a Hydrogen-storage Palladium Electrode with Teflon Covering to Increase Stability. Electrochemical Communications. 101: 73-77. DOI: https://doi.org/10.1016/j.elecom.2019.03.003.

[10] Nakayama, S., Onishi, K., Asahi, T., Lin, Y. and Kuwata, S. 2009. Response Characteristics of All-solid-state pH Sensor using $\mathrm{Li}_{5} \mathrm{YSi}_{4} \mathrm{O}_{12}$ Glass. Ceramics International. 35: 30573060 .

DOI: https://doi:10.1016/j.ceramint.2009.04.020.
[11] Tombacz, E. 2009. pH-dependent Surface Charging of Metal Oxides. Chemical Engineering. 53: 77-86. DOI: https://doi: 10.331 1/pp.ch.2009-2.08.

[12] Huang, P.-H., Huang, C.-W., Kang, C.-C., Hsu, C.-H., Lien, S.-Y., Wang, N.-F. and Huang, C.-J. 2020. The Investigation for Coating Method of Titanium Dioxide Layer in Perovskite Solar Cells. Crystals. 10: 236.

DOI: https:// doi:10.3390/cryst10030236.

[13] Johari, N. D., Rosli, Z. M., Juoi, J. M. and Yazid, S. A. 2019. Comparison on the $\mathrm{TiO}_{2}$ crystalline phases deposited via dip and spin coating using Green Sol-gel Route. Journal of Materials Research and Technology. 8(2): 2350-2358.

DOI: https://doi.org/10.1016/j.jmrt.2019.04.018.

[14] Abdullah, W. F. H., Othman, M. and Ali, M. A. M. 2009. Chemical Field-effect Transistor with Constant-voltage Constant-current Drain-source Readout Circuit. 2009 IEEE Student Conference on Research and Development (SCOReD). 219-221.

DOI: $10.1109 /$ SCORED 2009.5443112 .

[15] Al-Hilli, S. M., Al-Mofarji, R. T., Klason, P. and Willander, M. 2008. Zinc Oxide Nanorods Grown on Two-dimensional Macroporous Periodic Structures and Plane $\mathrm{Si}$ as a $\mathrm{pH}$ Sensor. 103, 014302. DOI: https://doi.org/10.1063/1.2826952.

[16] Huang, W. 2018. Surface Oxygen Vacancy-Controlled Reactivity of Hydroxyl Groups on Transitional Metal Oxide Surfaces. Encyclopedia of Interfacial Chemistry. 2018: 666672. DOI: https://doi.org/10.1016/B978-0-12-409547-2.14184-8.

[17] Wu, C.-Y., Tu, K.-J., Deng, J.-P., Lo, Y.-S. and Wu, C.-H. 2017. Markedly Enhanced Surface Hydroxyl Groups of $\mathrm{TiO}_{2}$ Nanoparticles with Superior Water-Dispersibility for Photocatalysis. Materials. 10(5): 566.

DOI: https:// doi:10.3390/ma10050566.

[18] Manjakkal, L., Szwagierczak, D. and Dahiya, R. 2020. Progress in Materials Science Metal Oxides based Electrochemical pH Sensors: Current Progress and Future Perspectives. Progress in Materials Science. 109: 100635. DOI: https://doi.org/10.1016/j.pmatsci.2019.100635

[19] Hussain, M., Ibupoto, Z. H., Abbasi, M. A., Nur, O. and Willander, M. 2014. Effect of Anions on the Morphology of $\mathrm{CO}_{3} \mathrm{O}_{4}$ Nanostructures Grown by Hydrothermal Method and their $\mathrm{pH}$ Sensing Application. Journal of Electroanalytical Chemistry. 717-718: 78-82.

DOI: https://doi.org/10.1016/j.jelechem.2014.01.011.

[20] Bousse, L. and Bergveld, P. 1984. The Role of Buried $\mathrm{OH}$ Sites in the Response Mechanism of Inorganic-Gate $\mathrm{pH}$ Sensitive ISFETs. Sensors and Actuators. 6: 65-78. DOI : https://doi.org/10.1016/0250-6874(84)80028-1.

[21] Pan, T. and Mondal, S. 2014. Structural Properties and Sensing Characteristics of Sensing Materials. Comprehensive Materials Processing. 13: 179-203. DOI: https://doi.org/10.1016/B978-0-08-096532-1.01306-6.

[22] Kurzweil, P. Metal Oxides and Ion-Exchanging Surfaces as $\mathrm{pH}$ Sensors in Liquids: State-of-the-Art and Outlook. Sensors. 9: 4955-4985.

DOI: https://doi:10.3390/s90604955.

[23] Chang, K.-M., Chang, C.-T., Chao, K.-Y. and Lin, C.-H. 2010. A Novel pH-dependent Drift Improvement Method for Zirconium Dioxide Gated pH-lon Sensitive Field Effect Transistors. Sensors. 10: 4643-4654. DOI: https://doi:10.3390/s100504643.

[24] Chou, J. C. and Wang, Y. F. 2002. Preparation and Study on the Drift and Hysteresis Properties of the Tin Oxide Gate ISFET by the Sol-gel Method. Sensors and Actuators B. 86: 58-62. DOI: https://doi.org/10.1016/S0925-4005(02)00147-8.

[25] Chou, J.-C. and Hsiao, C.-N. 2000. Drift Behavior of ISFETs with a-Si: $\mathrm{H}_{-} \mathrm{SiO}_{2}$ Gate Insulator. Materials Chemistry and Physics. 63: 270-273. DOl: https://doi.org/10.1016/S0254-0584(99)00188-1.

[26] Liao, Y.-H. and Chou, J.-C. 2009. Fabrication and Characterization of a Ruthenium Nitride Membrane for Electrochemical pH Sensors. Sensors. 9: 2478-2490. 
DOI: https://doi:10.3390/s90402478.

[27] McCafferty, E. and Wightman, J. P. 1998. Determination of the Concentration of Surface Hydroxyl Groups on Metal Oxide Films by a Quantitative XPS Method. Surface and Interface Analysis. 26: 549-564.

DOI: https://doi.org/10.1002/(SICl) 1096-9918(199807)26:8< 549::AID-SIA396>3.0.CO;2-Q.
[28] Yao, P.-C., Lee, M.-C. and Chiang, J.-L. 2014. Annealing Effect of Sol-Gel $\mathrm{TiO}_{2}$ Thin Film on pH-EGFET Sensor. 2014 International Symposium on Computer, Consumer and Control. 577-580.

DOI: https://doi:10.1109/IS3C.2014.157. 